\title{
Similar Trajectories in Current Alcohol Consumption and Tick-Borne Diseases: Only Parallel Changes in Time or Links Between?
}

\author{
Martyna Frątczak ${ }^{1}$, Branislav Petko ${ }^{1,2}$, Joanna H. Sliwowska ${ }^{1}$, Jan Szeptycki ${ }^{3}$ \\ and Piotr Tryjanowski ${ }^{{ }^{*}}$
}

${ }^{1}$ Department of Zoology, Poznań University of Life Sciences, Poznań, Poland, ${ }^{2}$ The University of Veterinary Medicine and Pharmacy in Košice, Košice, Slovakia, ${ }^{3}$ Department of Preclinical Sciences and Infectious Diseases, Poznań University of Life Sciences, Poznań, Poland

OPEN ACCESS

Edited by:

Michail Kotsyfakis, Academy of Sciences of the Czech Republic (ASCR), Czechia

Reviewed by: Shahid Karim, University of Southern Mississippi, United States

Ashley Groshong, Rocky Mountain Laboratories (NIAID),

United States

*Correspondence: Piotr Tryjanowski piotr.tryjanowski@gmail.com

Specialty section:

This article was submitted to

Parasite and Host,

a section of the journal

Frontiers in Cellular and

Infection Microbiology

Received: 12 October 2021 Accepted: 25 November 2021 Published: 16 December 2021

Citation:

Frątczak M, Petko B, Sliwowska JH, Szeptycki J and Tryjanowski P (2021) Similar Trajectories in Current Alcohol

Consumption and Tick-Borne

Diseases: Only Parallel Changes

in Time or Links Between?

Front. Cell. Infect. Microbiol. 11:790938.

doi: 10.3389/fcimb.2021.790938
In a modern world, both tick-borne diseases and alcohol consumption are among major public health threats. In the present opinion article, we pose the question, whether these two health problems: alcohol consumption and tick-borne diseases prevalence can be related. We hypothesize that it is possible due to at least three factors: outdoor places chosen for alcohol consumption, behavioral changes induced by alcohol, and possible stronger attraction of human hosts after alcohol consumption to ticks. Many important clues are coming from social studies about people's preference of places to consume alcohol and from studies regarding the attraction of people consuming alcohol to mosquitos. These data, however, cannot be directly transferred to the case of alcohol consumption and ticks. Therefore, we suggest that more detailed studies are needed to better understand the possible individual attractiveness of people to ticks and ways alcohol may influence it.

Keywords: ticks, tick-borne diseases, mosquitoes, alcohol consumption, outdoor activity

\section{INTRODUCTION}

Both tick-borne diseases and alcohol consumption are among major public health threats in the 21st century (Mansfield et al., 2017; WHO, 2021), whose importance has increased over the last decades. However, it is still puzzling if these two health problems changed only parallelly over the time axis, or are there any links between alcohol consumption and human attraction to ticks, and tick-borne pathogens? Thus, the main aim of this opinion paper is to indicate step by step potential interactions and then to discuss the above questions.

Ticks are second to mosquitoes as vectors of pathogens to humans and primary vectors of pathogens to domestic animals (Mansfield et al., 2017). The most important, from the human health perspective, species of ticks are representatives of Ixodidae family. The most common Ixodidae ticks in Europe, Ixodes ricinus and Dermacentor reticulatus, are known to transmit Borrelia burgdorferi s. 1. causing Lyme borreliosis, Anaplasma phagocytophilum causing human granulocytic anaplasmosis, Francisella tularensis causing tularaemia, Rickettsia bacteria, causing spotted fever rickettsiosis, 
Babesia bacteria, responsible for babesiosis, as well as tick-borne encephalitis virus, Louping ill virus and Tribec virus (Medlock et al., 2013).

Another representative of Ixodidae, an aggressive tick feeding on humans, Ambyomma americanum, very common in many regions of the North America, is a host of such important pathogens like Ehrlichia chaffeensis and Ehrlichia ewingii, causing human ehrlichiosis, as well as Rickettsia bacteria (Mixson et al., 2006).

Moreover, $I$. ricinus and $A$. amercianum ticks were recently linked to the development in human hosts a tick-borne allergic disease known as the alpha-Gal syndrome. In this syndrome, the immune response to antigens present in the tick saliva is leading to the anaphylaxis response to subsequent tick bites, red meat consumption and even intake of certain drugs (Commins and Platts-Mills, 2013; Commins, 2020; Fischer et al., 2020; Mitchell et al., 2020).

The distribution and activity of many tick species are changing, and the prevalence of human-tick contact, and tickborne diseases is increasing, especially within urban areas (Medlock et al., 2013; Sormunen et al., 2020). The changes in distribution of species, partly linked to climate changes, were noted for e.g., Ixodes ricinus and Dermacentor reticulatus in Europe (Alkishe et al., 2017) and Amblyomma americanum in North America (Dahlgren et al., 2016; Raghavan et al., 2019).

Moreover, it is also highly possible, that changing climate will lead in the future to expansion of novel, more exotic, tick species and pathogens they are carrying to Europe and North America, even more heightening the risk of developing tick-borne diseases (Ogden et al., 2021). Such events are already observed. For example, an African species of tick, Hyalomma rufipes, vector of dangerous Crimean Congo hemorrhagic fever virus (CCHFV), was noted in recent years in Greece and Italy (Lindeborg et al., 2012; Toma et al., 2021).

According to WHO data (WHO, 2021), alcohol consumption in developed and developing countries is constantly increasing. Globally, alcohol consumption causes 3 million deaths each year, leads to the development of many diseases and disabilities of millions of people. It is of particular interest for the current paper to explore if there are potential links between these two health risk factors: alcohol consumption and ticks' prevalence to human hosts?

Here, we hypothesize that these two health threats: alcohol and ticks may be linked due to the following factors: [1] outdoor places commonly chosen for alcohol consumption, [2] behavioral changes induced by alcohol, that lead to unresponsible activities and [3] possible stronger attraction of people to ticks caused by alcohol consumption.

To our best knowledge, these issues have not been studied yet, which is a bit surprising considering the popularity of alcohol consumption worldwide and the importance of tick-borne diseases prevention. We provided in this opinion not only potential links between two suggested factors but also pointed out the need for well-developed research in this area, which could have very practical implications for tick-borne diseases prevention.

\section{ALCOHOL IS OFTEN CONSUMED IN AREAS OF TICK OCCURRENCE}

In recent decades, species of common hard ticks in Europe, such as Ixodes ricinus, have significantly expanded their area of occurrence (Daniel et al., 2003; Jore et al., 2011; Jaenson et al., 2012) and are more and more often found in urban green areas where human exposure to ticks is very high. Importantly, in urban tick populations, a high prevalence of ticks infected with pathogens such as Borrelia burgdorferi, Rickettsiales and tickborne encephalitis virus has been detected (Biernat et al., 2014; Oechslin et al., 2017; Grochowska et al., 2020).

The dynamic shifts observed in the tick distribution and tickborne diseases prevalence are associated with the factors such as changes in land use, forest management and urban planning, changes of climate and in the distribution of tick-host species, as well as changes in human activity and lifestyle, resulting in greater exposure of people to infected ticks (Medlock et al., 2013). The latter aspect may be directly related to alcohol consumption. Social studies show that alcohol is very often consumed in green areas, also within cities. Drinking alcohol in green spaces is notably common among young people, especially exposed to the negative effects of alcohol consumption (Trell et al., 2014).

Although these observations can be treated as incidental, it is worth noticing, that green areas as a place of alcohol consumption and socializing became even more common during the ongoing Covid-19 pandemic, when in many countries under lockdown bars, pubs and restaurants were shut down. Interestingly, because of this, local authorities in some countries, like Canada, officially allowed drinking in city parks (City of North Vancouver, 2021; The Abbotsford News, 2021). It has been shown that people generally used green areas more intensively during pandemic than in previous years, even to the point of disruption of wildlife (Cukor et al., 2021).

Even if not taking Covid-19 pandemic to the picture, green areas are a very important space for human recreation (Stigsdotter and Grahn, 2011). Use of them may become even more popular due to the climatic changes, leading to prolongation of the warm weather season (Proebstl-Haider et al., 2021), causing people to have more contact with nature and dangers linked to it - like encountering ticks.

In most European countries, alcohol consumption is allowed from the age of 18, and in the United States from the age 21. The illegality of alcohol consumption by younger people leads many of them to experiment with alcohol outside the home. When they decide to drink alcohol, they usually choose secluded places and out of the reach of any form of external control (such as adults, police) (Percy et al., 2011; Townshend and Roberts, 2013). In one study, $29 \%$ of 15 -year-olds admitted drinking outdoors, in city parks and similar locations (Hawkins, 2012). Several other studies also found (Valentine et al., 2010) that adolescents typically consume alcohol in so-called marginal public places, such as streets, bus stops, green spaces, and parks.

In the literature related to the threats caused by alcohol, different styles of its consumption are evident. One of them is the 
so-called binge drinking, i.e., episodic drinking in which huge amounts of alcohol are consumed in a short time, for example during the weekend. This pattern of alcohol consumption is common in groups of students who meet on weekends after a week of studying (Erickson, 2018). Such a drinking style can be especially dangerous when happening outside, due to causing irresponsible behaviors.

Choosing to drink alcohol outdoors may have different risks than drinking alcohol in pubs, clubs, or residential buildings. These risks include exposure to ticks and tick-borne diseases. Alcohol influences the locomotor behavior and decision-making of people (Lang et al., 2003; Lorant et al., 2013). Individuals after consumption of alcohol may walk uncarefully and in a changed trajectory, walking around a larger space than sober individuals. It is also not uncommon for people after excessive alcohol consumption to fall or choose random places outside to rest or sleep. In this way, the risk of encountering a tick may be higher for drunken people.

It is worth noting, that infections with tick-borne diseases are very often recorded in mushroom pickers, who admit going to the forest under the influence of alcohol (Iowa State University, 2021). Although they are generally a group exposed to the contact with ticks, information about this additional health risk could encourage them to use better tick protection. Among social groups, homeless people are especially prone to both alcohol consumption problems and tick-borne diseases (Bransfield, 2018).

\section{POSSIBLE STRONGER ATTRACTION TO TICKS AFTER ALCOHOL CONSUMPTION}

The behavior of ticks when selecting an appropriate host can be divided into two phases: the host-finding behavior and the hostdiscrimination behavior. The most common ticks in Europe, family Ixodidae, look for suitable hosts in a very distinctive way, climbing over vegetation and waiting for it with outstretched legs. Several physical and chemical stimuli (non-specific for a host, like $\mathrm{CO}_{2}$, body heat, vibrations) inform the waiting tick about a potential host passing by (Lees, 1948; Camin and Drenner, 1978). If a potential host encounters a tick, the arachnid climbs onto it and then starts foraging or falls to the ground and starts the host-finding phase again. The choice or rejection of the host is based on host-specific physical and chemical stimuli, like individual body odor (Camin and Drenner, 1978; Steullet and Guerin, 1992). Different, and very often described as aggressive, strategy of acquiring the host can be found in A. americanum and some other ticks from the order Amblyomma. They use an active hunter strategy, in which they emerge from the habitat and run toward the potential host, that occurred nearby (Parola and Raoult, 2001).

Ixodidae ticks have highly sensitive chemical receptors, detecting, among others, $\mathrm{CO}_{2}$ and $\mathrm{NH}_{3}$, phenols and other substances that make up the host's odor (Lees, 1948). The most important sensory organ of the tick is the Haller's organ. It is located in the front pair of tick legs, playing a role analogous to insect antennas. The Haller's organ contains receptors that respond to subtle changes in $\mathrm{CO}_{2}$ concentrations in the environment (Steullet and Guerin, 1992) and a variety of other compounds found in the host's odour (Steullet and Guerin, 1994; Leonovich, 2004). Haller's organ has been suggested to play a role in the perception of other stimuli as well, e.g., infrared light (Mitchell et al., 2017). Ticks can respond to the environment also due to numerous sensory bristles in the body and on the legs, which detect olfactory and thermal stimuli as well as the level of air humidity (Lees, 1969; Waladde, 1977). The sense organs include also the so-called areae porosae, a pair of depressions at the base of the head in female Ixodidae ticks (Woolley, 1972; Hess and Vlimant, 1986). It is believed that hunger and the detection of certain chemicals in the environment is the greatest motivating force for ticks to find a suitable host. Only unfed ticks have been shown to exhibit behavioral responses to odors, which confirms these stimuli are active during questing behaviors (Leonovich, 2004).

Human hosts may become more attractive to ticks after alcohol consumption through at least several mechanisms. Alcohol causes stronger sweating, dilatation of blood vessels, increases body temperature, emission of body heat and $\mathrm{CO}_{2}$ (Malpas et al., 1990; Desruelle et al, 1996; Wolf et al., 1999; Yoda et al., 2005). This way stimuli attracting ticks can be much stronger in the case of drunken individuals. It has been shown, that especially for ticks using hunting strategy of seeking a host, like A. americanum, $\mathrm{CO}_{2}$ is an extremely strong attractant (Carr et al., 2013). People after alcohol ingestion, emitting more $\mathrm{CO}_{2}$, could be particularly prone to attack of these active parasites.

\section{ALCOHOL AS A REMEDY FOR TICKS?}

When discussing links between alcohol and ticks, it is worth to notice, that some people use alcohol as traditional repellent of ticks. For example, in a study concerning Polish and Czech university students' attitude toward tick-borne diseases (Nejezchlebová et al., 2016) it was shown, that some of them use alcohol to avoid tick bites (although it was not specified, if they use it externally or internally). Other home remedies for tick's protection included vitamins from group B and yeasts, that can also be found in beer. The real efficiency of such practices in tick borne diseases prevention is however doubtful.

Some tick "natural" repellent products are herbal infusions in alcohol, intended to apply externally (Lupi et al., 2013). They are usually not considered as very effective, due to the fact that product containing alcohol permeate deep into the skin, which for the external repellent means faster loss of protection (Bissinger and Roe, 2010). It is also quite popular to use alcohol to remove ticks from the skin, with the expectation that arachnid will drown in it. However, much more effective is to simply pull the tick out with tweezers, an eventually later dispose the tick by putting it into alcohol (CDC, 2021).

Similarly, being under the influence of alcohol does not protect from ticks. The amount of alcohol in blood consumed by the tick will be not sufficient to kill the insect. It may work for a small fruit fly Drosophila melanogaster to protect itself from 
blood-borne parasites by ingestion of alcohol (Milan et al., 2012) but not for a human body. If the concentration of alcohol in human blood would be high enough to kill the tick, it would probably also contribute to the death of the host itself.

\section{DISCUSSION}

The hypothesis that alcohol consumers may be attractive to ticks more than sober individuals has some basis in studies regarding other blood-sucking arthropods, reacting to similar stimuli as ticks (Figure 1).

It has been shown that people in short time after alcohol consumption attract more mosquitoes than those who do not (Shirai et al., 2002). The reason may lay in higher production of sweat, $\mathrm{CO}_{2}$ and greater emission of heat in the human body after alcohol consumption (Malpas et al., 1990; Desruelle et al., 1996; Wolf et al., 1999; Yoda et al., 2005). Both $\mathrm{CO}_{2}$ and heat generated by the human body are strong attractants for mosquitoes (Brown et al., 1951; Smart and Brown, 1956; Eiras and Jepson, 1994). Mosquitoes have also been shown to be attracted to increased sweat production (Khan et al., 1969; Maibach et al., 1996; Healy and Copland, 2000). Some researchers believe that increased exposure to mosquitoes after drinking alcohol is related to behavioral factors - people under the influence of alcohol may move more slowly and be easier to attack by mosquitoes (Shirai et al., 2002; Lefèvre et al., 2010). These effects of alcohol on humans could also influence the risk of contact with ticks.
Estimating the risk of human exposure to ectoparasites is usually based on the assumption that all people in the population are attractive to them to the same degree. However, observations and numerous studies show that it is not always the truth. Studies of Anopheles mosquito, a vector of malaria, bites prevalence show that humans differ greatly in their attractiveness to mosquitos (Brady et al., 1997; Kelly, 2001; Qiu et al., 2006). One study showed that only $20 \%$ of the population is responsible for more than $80 \%$ of all malaria infections in African children (Smith et al., 2005).

Each person has a characteristic body odour that is a result of the emission of more than several hundred volatile organic compounds present in the breath and emitted by the skin (products of glandular secretions interacting with skin bacteria) (Roberts et al., 2005; Lenochova and Havlicek, 2008). Additional factors such as diet, overall health, or even reproductive status and endocrine system functions may also influence an individual's olfactory signal (Lindsay et al., 2000; Roberts et al., 2005; Havlicek and Lenochova, 2006). These factors are believed to be partly a cause of the observed varying degree of human attractiveness to malaria mosquitoes. For example, pregnant women are twice as attractive to Anopheles mosquitoes, and hence more likely to contract malaria, than non-pregnant women (Himeidan et al., 2004). Recent research on this topic has shown that beer consumption also affects people's attractiveness to malaria mosquitoes (Healy and Copland, 2000). The body odour of people who consumed beer attracted mosquitoes much more than the smell of people who did not drink beer.

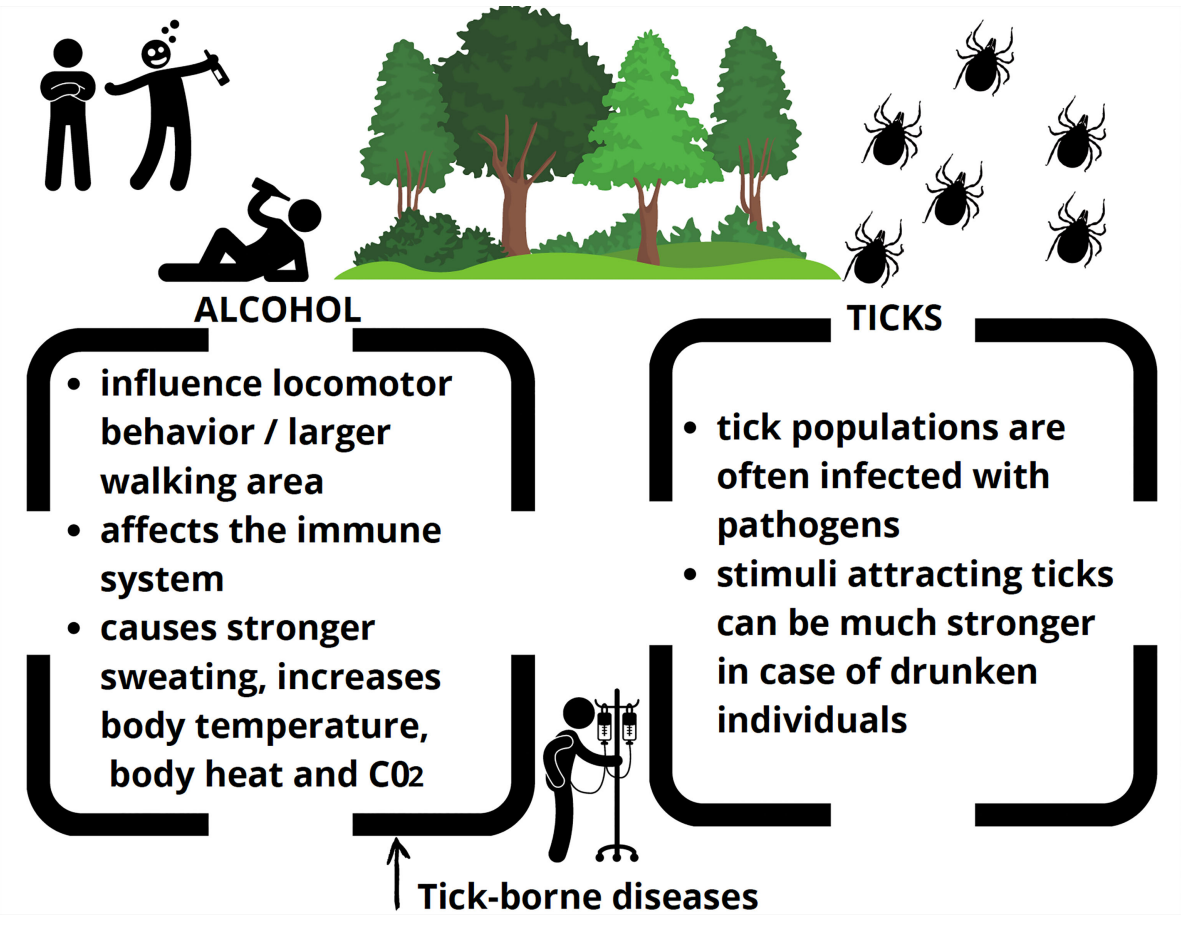

FIGURE 1 | Graphical summary of the ideas described in the text. 
Anecdotal observations suggest that, as in the case of attractiveness to mosquitoes, people's attractiveness to ticks is also subject to variability in the population. So far, however, there has been little research into the individual attractiveness of people to ticks. It has been shown that under controlled conditions, ticks of the Amblyomma americanum species are attracted more to air exhaled by women than by men (Josek et al., 2019). It is possible then, that potential metabolic differences between men and women, or sex hormones, play an important role in making an individual more attractive to ticks, but it needs more study in the future.

A review of the available literature indicates a strong need for studies focused on links between alcohol consumption and tick bites and tick-borne diseases prevalence in the human population. There are many possible ways in which these health problems can be related. Detailed experiments are needed to understand possible individual attractiveness to ticks and other vectors and ways the alcohol may influence it. An additional comparison worth a greater understanding is sex-related difference in the attractiveness of people to ticks and mosquitos.

Although alcohol is linked to the much more obvious dangers (like car accidents or developing liver problems), it could be beneficial for preventive medicine to find out, if it is also a risk factor of tick-borne and other vector-borne diseases. Awareness of such possibility could encourage people to better protection from ticks, when enjoying time in green areas.

\section{REFERENCES}

Alkishe, A. A., Peterson, A. T., and Samy, A. M. (2017). Climate Change Influences on the Potential Geographic Distribution of the Disease Vector Tick Ixodes Ricinus. PloS One 12 (12), e0189092. doi: 10.1371/journal.pone.0189092

Biernat, B., Karbowiak, G., Werszko, J., and Stańczak, J. (2014). Prevalence of Tick-Borne Encephalitis Virus (TBEV) RNA in Dermacentor Reticulatus Ticks From Natural and Urban Environment, Poland. Exp. Appl. Acarol. 64 (4), 543551. doi: 10.1007/s10493-014-9836-5

Bissinger, B. W., and Roe, R. M. (2010). Tick Repellents: Past, Present, and Future. Pestic. Biochem. Physiol. 96 (2), 63-79. doi: 10.1016/j.pestbp.2009.09.010

Brady, J., Costantini, C., Sagnon, N., Gibson, G., and Coluzzi, M. (1997). The Role of Body Odours in the Relative Attractiveness of Different Men to Malarial Vectors in Burkina Faso. Ann. Trop. Med. Parasitol. 91, 121-122. doi: 10.1080/ 00034983.1997.11813252

Bransfield, R. C. (2018). Aggressiveness, Violence, Homicidality, Homicide, and Lyme Disease). Neuropsychiatr. Dis. Treat. 14, 693. doi: 10.2147/NDT.S155143

Brown, A. W. A., Sarkaria, D. S., and Thompson, R. P. (1951). Studies on the Responses of the Female Aedes Mosquito. Part I.-The Search for Attractant Vapours. Bull. Entomol. Res. 42, 105-110. doi: 10.1017/S0007485300025189

Camin, J. H., and Drenner, R. W. (1978). Climbing Behavior and Host-Finding of Larval Rabbit Ticks (Haemaphysalis Leporispalustris). J. Parasitol. 64(5), 905909. doi: $10.2307 / 3279529$

Carr, A. L., Roe, R. M., Arellano, C., Sonenshine, D. E., Schal, C., and Apperson, C. S. (2013). Responses of Amblyomma Americanum and Dermacentor Variabilis to Odorants That Attract Haematophagous Insects. Med. Vet. Entomol. 27 (1), 86-95. doi: 10.1111/j.1365-2915.2012.01024.x

CDC. Centers for Disease Control and Prevention. (2021). Ticks: Removing a Tick. Available at: https://www.cdc.gov/ticks/removing_a_tick.html (Accessed 4 October 2021).

City of North Vancouver. (2021). Available at: https:/www.cnv.org/city-services/ health-and-public-safety/alcohol-in-public-spaces (Accessed 4 October 2021).

Commins, S. P. (2020). Diagnosis \& Management of Alpha-Gal Syndrome: Lessons From 2,500 Patients. Expert Rev. Clin. Immunol. 16 (7), 667-677. doi: 10.1080/1744666X.2020.1782745

\section{DATA AVAILABILITY STATEMENT}

The original contributions presented in the study are included in the article/supplementary material. Further inquiries can be directed to the corresponding author.

\section{AUTHOR CONTRIBUTIONS}

All authors reviewed the current knowledge, included their views of the discussed topic, edited, and read the manuscript. All authors contributed to the article and approved the submitted version.

\section{FUNDING}

Research conducted by the statutory funding No. 506.511.05.00 of the Faculty of Veterinary Medicine and Animal Science Poznan University of Life Sciences, Poland; Department of Zoology (MF, JHS, JS, and PT). This work was supported by the Slovak Research and Development Agency under the Contract no. APVV-19-0440 (to BP).

\section{ACKNOWLEDGMENTS}

We thank Dr Emilia Grzeda for preparing the Figure.

Commins, S. P., and Platts-Mills, T. A. (2013). Delayed Anaphylaxis to Red Meat in Patients With IgE Specific for Galactose Alpha-1, 3-Galactose (Alpha-Gal). Curr. Allergy Asthma Rep. 13 (1), 72-77. doi: 10.1007/s11882-012-0315-y

Cukor, J., Linda, R., Mahlerová, K., Vacek, Z., Faltusová, M., Marada, P., et al (2021). Different Patterns of Human Activities in Nature During Covid-19 Pandemic and African Swine Fever Outbreak Confirm Direct Impact on Wildlife Disruption. Sci. Rep. 11 (1), 1-11. doi: 10.1038/s41598-02199862-0

Dahlgren, F. S., Paddock, C. D., Springer, Y. P., Eisen, R. J., and Behravesh, C. B. (2016). Expanding Range of Amblyomma Americanum and Simultaneous Changes in the Epidemiology of Spotted Fever Group Rickettsiosis in the United States. Am. J. Trop. Med. 94 (1), 35. doi: 10.4269/ajtmh.15-0580

Daniel, M., Danielova, V., Křriž, B., Jirsa, A., and Nožička, J. (2003). Shift of the Tick Ixodes Ricinus and Tick-Borne Encephalitis to Higher Altitudes in Central Europe. Eur. J. Clin. Microbiol. Infect. Dis. 22, 327-328. doi: 10.1007/s10096-003-0918-2

Desruelle, A., Boisvert, V. P., and Candas, V. (1996). Alcohol and Its Variable Effect on Human Thermoregulatory Response to Exercise in a Warm Environment. Eur. J. Appl. Physiol. 74, 572-574. doi: 10.1007/BF02376775

Eiras, A. E., and Jepson, P. C. (1994). Responses of Female Aedes Aegypti (Diptera: Culicidae) to Host Odours and Convection Currents Using an Olfactometer Bioassay. Bull. Entomol. Res. 84, 207-211. doi: 10.1017/S0007485300039705

Erickson, C. K. (2018). The Science of Addiction: From Neurobiology to Treatment (New York, NY, USA: WW Norton \& Company).

Fischer, J., Riel, S., Fehrenbacher, B., Frank, A., Schaller, M., Biedermann, T., et al (2020). Spatial Distribution of Alpha-Gal in Ixodes Ricinus-a Histological Study. Ticks Tick Borne Dis. 11 (5), 101506. doi: 10.1016/j.ttbdis.2020.101506 Grochowska, A., Milewski, R., Pancewicz, S., Dunaj, J., Czupryna, P. , Milewska, A. J., et al (2020). Comparison of Tick-Borne Pathogen Prevalence in Ixodes Ricinus Ticks Collected in Urban Areas of Europe. Sci. Rep. 10, 1-9. doi: 10.1038/s41598-020-63883-y

Havlicek, J., and Lenochova, P. (2006). The Effect of Meat Consumption on Body Odor Attractiveness. Chem. Senses 31, 747-752. doi: 10.1093/chemse/bj1017

Hawkins, V. (2012). Smoking, Drinking and Drug Use Among Young People in England in 2011 (London: Health and Social Care Information). 
Healy, T. P., and Copland, M. J. W. (2000). Human Sweat and 2-Oxopentanoic Acid Elicit a Landing Response From Anopheles Gambiae. Med. Vet. Entomol. 14, 195-200. doi: 10.1046/j.1365-2915.2000.00238.x

Hess, E., and Vlimant, M. (1986). "Leg Sense Organs of Ticks," in Morphology, Physiology, and Behavioral Biology of Ticks (John Wiley \& Sons), 361-390.

Himeidan, Y. E., Elbashir, M. I., and Adam, I. (2004). Attractiveness of Pregnant Women to the Malaria Vector, Anopheles Arabiensis, in Sudan. Ann. Trop. Med. Parasitol. 98, 631-633. doi: 10.1179/000349804225021307

Iowa State University. (2021). Extension and Outreach. Ticks and Alcohol. Available at: https://hortnews.extension.iastate.edu/2011/5-18/ticks.html (Accessed 4 October 2021).

Jaenson, T. G., Jaenson, D. G., Eisen, L., Petersson, E., and Lindgren, E. (2012). Changes in the Geographical Distribution and Abundance of the Tick Ixodes Ricinus During the Past 30 Years in Sweden. Parasites Vectors 5, 8. doi: 10.1186/1756-3305-5-8

Jore, S., Viljugrein, H., Hofshagen, M., Brun-Hansen, H., Kristoffersen, A. B., and Nygård, K. (2011). Multi-Source Analysis Reveals Latitudinal and Altitudinal Shifts in Range of Ixodes Ricinus at Its Northern Distribution Limit. Parasites Vectors 4, 84. doi: 10.1186/1756-3305-4-84

Josek, T., Gardner, A. M., Hedlund, T. J., Parker, A. T., Updyke, E. A., and Allan, B. F. (2019). Fatal Attraction: Lone Star Ticks (Amblyomma Americanum) Exhibit Preference for Human Female Breath Over Male Breath. Exp. Appl. Acarol. 77, 59-64. doi: 10.1007/s10493-018-00338-0

Kelly, D. W. (2001). Why Are Some People Bitten More Than Others? Trends Parasitol. 17, 578-581. doi: 10.1016/s1471-4922(01)02116-x

Khan, A. A., Maibach, H. I., Strauss, W. G., and Fisher, J. L. (1969). Increased Atffactiveness of Man to Mosquitoes With Induced Eccrine Sweating. Nature 223, 859-860. doi: 10.1038/223859a0

Lang, C., Tay, R., Watson, B., Edmonston, C., and O’Connor, E. (2003). “Drink Walking: An Examination of the Related Behaviour and Attitudes of Young People. "Roads and Traffic Authority of New South Wales"," in Road Safety Research, Policing and Education Conference (Sydney NSW, Australia), p. 164169.

Lees, A. D. (1948). The Sensory Physiology of the Sheep Tick, Ixodes Ricinus L. J. Exp. Biol. 25, 145-207. doi: 10.1242/jeb.25.2.145

Lees, A. D. (1969). Behavior and Physiology of Ticks. Acarologia 11 (3), 397-410.

Lefèvre, T., Gouagna, L. C., Dabiré, K. R., Elguero, E., Fontenille, D., Renaud, F., et al (2010). Beer Consumption Increases Human Attractiveness to Malaria Mosquitoes. PloS One 5, e9546. doi: 10.1371/journal.pone.0009546

Lenochova, P., and Havlicek, J. (2008). "Human Body Odour Individuality," in Chemical Signals in Vertebrates 11 (New York: Springer), 189-198. doi: 10.1007/978-0-387-73945-8_18

Leonovich, S. A. (2004). Phenol and Lactone Receptors in the Distal Sensilla of the Haller's Organ in Ixodes Ricinus Ticks and Their Possible Role in Host Perception. Exp. Appl. Acarol. 32, 89-102. doi: 10.1023/b:appa.0000018200. 24760.78

Lindeborg, M., Barboutis, C., Ehrenborg, C., Fransson, T., Jaenson, T. G., Lindgren, P. E., et al (2012). Migratory Birds, Ticks, and Crimean-Congo Hemorrhagic Fever Virus. Emerg. Infect. Dis. 18 (12), 2095. doi: 10.3201/ eid1812.120718

Lindsay, S., Ansell, J., Selman, C., Cox, V., Hamilton, K., and Walraven, G. (2000). Effect of Pregnancy on Exposure to Malaria Mosquitoes. Lancet 355, 1972. doi: 10.1016/S0140-6736(00)02334-5

Lorant, V., Nicaise, P., Soto, V. E., and d'Hoore, W. (2013). Alcohol Drinking Among College Students: College Responsibility for Personal Troubles. BMC Public Health 13, 1-9. doi: 10.1186/1471-2458-13-615

Lupi, E., Hatz, C., and Schlagenhauf, P. (2013). The Efficacy of Repellents Against Aedes, Anopheles, Culex and Ixodes Spp.-A Literature Review. Travel. Med. Infect. Dis. 11 (6), 374-411. doi: 10.1016/j.tmaid.2013.10.005

Maibach, H. I., Khan, A. A., Strauss, W. G., and Pearson, T. R. (1996). Attraction of Anhidrotic Subjects to Mosquitoes. Arch. Dermatol. 94, 215-217. doi: 10.1001/archderm.1966.01600260107017

Malpas, S. C., Robinson, B. J., and Maling, T. J. B. (1990). Mechanism of EthanolInduced Vasodilation. J. Appl. Physiol. 68 (2), 731-734. doi: 10.1152/ jappl.1990.68.2.731

Mansfield, K. L., Jizhou, L., Phipps, L. P., and Johnson, N. (2017). Emerging TickBorne Viruses in the Twenty-First Century. Front. Cell. Infect. Microbiol. 7, 298. doi: $10.3389 /$ fcimb. 2017.00298
Medlock, J. M., Hansford, K. M., Bormane, A., Derdakova, M., Estrada-Peña, A., George, J. C., et al (2013). Driving Forces for Changes in Geographical Distribution of Ixodes Ricinus Ticks in Europe. Parasites Vectors 6, 1. doi: 10.1186/1756-3305-6-1

Milan, N. F., Kacsoh, B. Z., and Schlenke, T. A. (2012). Alcohol Consumption as Self-Medication Against Blood-Borne Parasites in the Fruit Fly. Curr. Biol. 22 (6), 488-493. doi: 10.1016/j.cub.2012.01.045

Mitchell, C. L., Lin, F. C., Vaughn, M., Apperson, C. S., Meshnick, S. R., and Commins, S. P. (2020). Association Between Lone Star Tick Bites and Increased Alpha-Gal Sensitization: Evidence From a Prospective Cohort of Outdoor Workers. Parasites Vectors 13 (1), 1-4. doi: 10.1186/s13071-02004343-4

Mitchell, R. D.III, Zhu, J., Carr, A. L., Dhammi, A., Cave, G., Sonenshine, D. E., et al (2017). Infrared Light Detection by the Haller's Organ of Adult American Dog Ticks, Dermacentor Variabilis (Ixodida: Ixodidae). Ticks Tick Borne Dis. 8, 764-771. doi: 10.1016/j.ttbdis.2017.06.001

Mixson, T. R., Campbell, S. R., Gill, J. S., Ginsberg, H. S., Reichard, M. V., Schulze, T. L., et al (2006). Prevalence of Ehrlichia, Borrelia, and Rickettsial Agents in Amblyomma Americanum (Acari: Ixodidae) Collected From Nine States. J. Med. Entomol. 43 (6), 1261-1268. doi: 10.1603/0022-2585(2006)43[1261: poebar]2.0.co;2

Nejezchlebová, H., Kiewra, D., Žákovská, A., and Ovesná, P. (2016). Students' Attitudes to Tick Risks. Ann. Agric. Environ. Med. 23 (3), 437-441. doi: 10.5604/12321966.1219183

Oechslin, C. P., Heutschi, D., Lenz, N., Tischhauser, W., Péter, O., Rais, O., et al (2017). Prevalence of Tick-Borne Pathogens in Questing Ixodes Ricinus Ticks in Urban and Suburban Areas of Switzerland. Parasites Vectors 10 (1), 1-18. doi: 10.1186/s13071-017-2500-2

Ogden, N. H., Ben Beard, C., Ginsberg, H. S., and Tsao, J. I. (2021). Possible Effects of Climate Change on Ixodid Ticks and the Pathogens They Transmit: Predictions and Observations. J. Med. Entomol. 58 (4), 1536-1545. doi: 10.1093/jme/tjaa220

Parola, P., and Raoult, D. (2001). Ticks and Tickborne Bacterial Diseases in Humans: An Emerging Infectious Threat. Clin. Infect. Dis. 32 (6), 897-928. doi: $10.1086 / 319347$

Percy, A., Wilson, J., McCartan, C., and McCrystal, P. (2011). Teenage Drinking Cultures (York: Josephy Rowntree Foundation).

Proebstl-Haider, U., Hoedl, C., Ginner, K., and Borgwardt, F. (2021). Climate Change: Impacts on Outdoor Activities in the Summer and Shoulder Seasons. J. Outdoor Recreat. Tour. 34, 100344. doi: 10.1016/j.jort.2020.100344

Qiu, Y. T., Smallegange, R. C., Van Loon, J. J. A., Ter Braak, C. J. F., and Takken, W. (2006). Interindividual Variation in the Attractiveness of Human Odours to the Malaria Mosquito Anopheles Gambiae s.s. Med. Vet. Entomol. 20, 280-287. doi: 10.1111/j.1365-2915.2006.00627.x

Raghavan, R. K., Peterson, A. T., Cobos, M. E., Ganta, R., and Foley, D. (2019). Current and Future Distribution of the Lone Star Tick, Amblyomma Americanum (L.) (Acari: Ixodidae) in North America. PloS One 14 (1), e0209082. doi: 10.1371/journal.pone.0209082

Roberts, S. C., Gosling, L. M., Spector, T. D., Miller, P., Penn, D. J., and Petrie, M. (2005). Body Odor Similarity in Noncohabiting Twins. Chem. Senses 30, 651656. doi: 10.1093/chemse/bji058

Shirai, O., Tsuda, T., Kitagawa, S., Naitoh, K., Seki, T., Kamimura, K., et al (2002). Alcohol Ingestion Stimulates Mosquito Attraction. J. Am. Mosq. Control. Assoc. 18, 91-96.

Smart, M. R., and Brown, A. W. A. (1956). Studies on the Responses of the Female Aedes Mosquito. Part VII.-The Effect of Skin Temperature, Hue and Moisture on the Attractiveness of the Human Hand. Bull. Entomol. Res. 47, 89-101. doi: $10.1017 /$ S000748530004654X

Smith, D. L., Dushoff, J., Snow, R. W., and Hay, S. I. (2005). The Entomological Inoculation Rate and Plasmodium Falciparum Infection in African Children. Nature 438, 492-495. doi: 10.1038/nature04024

Sormunen, J. J., Kulha, N., Klemola, T., Mäkelä, S., Vesilahti, E. M., and Vesterinen, E. J. (2020). Enhanced Threat of Tick-Borne Infections Within Cities? Assessing Public Health Risks Due to Ticks in Urban Green Spaces in Helsinki, Finland. Zoonoses Public Health 67, 823-839. doi: 10.1111/zph.12767

Steullet, P., and Guerin, P. M. (1992). Perception of Breath Components by the Tropical Bont Tick, Amblyomma Variegatum Fabricius (Ixodidae). J. Comp Physiol. 170, 665-676. doi: 10.1007/BF00198976 
Steullet, P., and Guerin, P. M. (1994). Identification of Vertebrate Volatiles Stimulating Olfactory Receptors on Tarsus I of the Tick Amblyomma Variegatum Fabricius (Ixodidae). J. Comp. Physiol. 174, 27-38. doi: 10.1007/ BF00192003

Stigsdotter, U. K., and Grahn, P. (2011). Stressed Individuals' Preferences for Activities and Environmental Characteristics in Green Spaces. Urban For. Urban Green 10 (4), 295-304. doi: 10.1016/j.ufug.2011.07.001

The Abbotsford News. (2021). Available at: https://www.abbynews.com/news/ drinking-in-two-city-parks-to-be-allowed-by-chilliwack-council (Accessed 4 October 2021).

Toma, L., Mancuso, E., d'Alessio, S. G., Menegon, M., Spina, F., Pascucci, I., et al (2021). Tick Species From Africa by Migratory Birds: A 3-Year Study in Italy. Exp. Appl. Acarol. 83 (1), 147-164. doi: 10.1007/s10493-020-00573-4

Townshend, T. G., and Roberts, M. (2013). Affordances, Young People, Parks and Alcohol Consumption. J. Urban Des. 18, 494-516. doi: 10.1080/13574809.2013.835696

Trell, E. M., van Hoven, B., and Huigen, P. P. (2014). 'In Summer We Go and Drink at the Lake': Young Men and the Geographies of Alcohol and Drinking in Rural Estonia. Child Geogr. 12, 447-463. doi: 10.1080/14733285.2013.824740

Valentine, G. S., Holloway, L., and Jayne, M. (2010). Generational Patterns of Alcohol Consumption: Continuity and Change. Health Place 16, 916-925. doi: $10.1016 /$ j.healthplace.2010.05.003

Waladde, S. M. (1977). The Sensory Nervous System of the Adult Cattle Tick Boophilus Microplus (Canestrini) Ixodidae Part II. Scan. Electron Microsc. Aust. J. Entomol. 16 (1), 73-79. doi: 10.1111/j.1440-6055.1977.tb00064.x

Wolf, R., Tuzun, B., and Tuzun, Y. (1999). Alcohol Ingestion and the Cutaneous Vasculature. Clin. Dermatol. 17, 395-403. doi: 10.1016/S0738-081X(99)00023-1
Woolley, T. A. (1972). Some Sense Organs of Ticks as Seen by Scanning Electron Microscopy. Trans. Am. Microsc. Soc. 91, 35-47. doi: 10.2307/3224855

World Health Organization (2021). Health Topics: Alcohol. Available at: https:// www.who.int/health-topics/alcohol\#tab=tab_1 (Accessed 4 October 2021).

Yoda, T., Crawshaw, L. I., Nakamura, M., Saito, K., Konishi, A. , Nagashima, K., et al (2005). Effects of Alcohol on Thermoregulation During Mild Heat Exposure in Humans. Alcohol 36, 195-200. doi: 10.1016/j.alcohol.2005.09.002

Conflict of Interest: The authors declare that the research was conducted in the absence of any commercial or financial relationships that could be construed as a potential conflict of interest.

Publisher's Note: All claims expressed in this article are solely those of the authors and do not necessarily represent those of their affiliated organizations, or those of the publisher, the editors and the reviewers. Any product that may be evaluated in this article, or claim that may be made by its manufacturer, is not guaranteed or endorsed by the publisher.

Copyright (C) 2021 Frątczak, Petko, Sliwowska, Szeptycki and Tryjanowski. This is an open-access article distributed under the terms of the Creative Commons Attribution License (CC BY). The use, distribution or reproduction in other forums is permitted, provided the original author(s) and the copyright owner(s) are credited and that the original publication in this journal is cited, in accordance with accepted academic practice. No use, distribution or reproduction is permitted which does not comply with these terms. 